\title{
Sustainable Business Development in the Context of Logistics in the Globalization Process
}

\author{
Pavel Ceniga ${ }^{1, *}$, Viera Sukalova ${ }^{2}$ \\ ${ }^{1}$ University of Zilina, Faculty of Operation and Economics of Transport and Communications, \\ Department of Economics, Univerzitna 1, 01026 Zilina, Slovak Republic \\ ${ }^{2}$ University of Zilina, Faculty of Operation and Economics of Transport and Communications, \\ Department of Economics, Univerzitna 1, 01026 Zilina, Slovak Republic
}

\begin{abstract}
The world and society constantly evolving and now in the era of information technology and globalization, this development is much faster. This rapid pace poses a higher risk of causing negative impacts on man and his environment, whether it is the excessive production of waste or excessive exploitation of limited natural resources. Ensuring sustainability is essential to us and the awareness of this need has brought about the concept of sustainable development that regulates the satisfaction of the needs of the present generation so that future generations are not threatened. In this context, the article deals with one of the keys to sustainable mobility, which, according to the European Parliament, is an efficient and effective cost logistics as an integral part of the transport system needed for economic performance, competitiveness and environmental protection. The aim of the article is to introduce sustainable logistics and to point out the importance of its application in the company with the aim of eliminating the impact of these processes on the environment and human beings in the context of continuing globalization. To achieve research goals we used methodology included historical method, desk review, and system analysis and field research.
\end{abstract}

\section{Introduction}

In recent decades, humanity has slowly begun to realize that the unregulated development or growth that has taken place in the environment of our planet's limited resources has been unsustainable for a long time. It is necessary to replace it with something more sustainable in the interest of both humanity and the biosphere. In 1987, the UN General Assembly adopted the report "Our Common Future", in which sustainable development was defined as a development that is capable of meeting the needs of current generations without jeopardizing future generations' ability to meet their own needs. In particular, this definition contains the basic principle of sustainability, an ethical leitmotif, the principle of accountability to future generations. We always talk about sustainable development when we realize the link between human needs and natural resources. Sustainable development is

* Corresponding author : pavel.ceniga@fpedas.uniza.sk 
the way to find and find solutions that benefit people, the economy and the environment in the long term. Thus, sustainable development is, rather than a scientific solution, a moral challenge for society. It responds to the current and important need for future development, based on a new relationship between people and their relationship to the environment in which they live. She refuses to overcome the idea that economic, technical and environmental goals are against each other.

Transport logistics can be seen as one of the key activities of the logistics process, which in financial terms often represents the largest cost item in relation to other logistics activities such as storage, material handling, procurement, inventory management, information systems, customer service etc. The role of transport logistics is to provide the transport process so that the desired benefits are created: the benefit of the site - to move any item where required and the benefit of time - to move the item when it is required. In this way, transport logistics is becoming an important pillar of a logistics system that can be defined as a purpose-built physical and management structure that enables the activation, assurance, evaluation and improvement of the flow of logistics networks. [1] In the context of European Union policy, the European Commission in "Freight Transport Logistics in Europe - the key to the development of sustainable mobility", presents the view that optimization of the European transport system would be possible through the use of a logistics concept.

Green logistics is a subsystem of eco-logistics as an application area of logistics; its main focus is on monitoring, evaluation, reducing the negative impacts of various industrial activities on the environment and individual components of the environment. In addition to legislation, the development of green logistics is also influenced by consumers' interests in those products and services that have the least impact on the environment, both during production, consumption and after the end of the life cycle, when products become waste. Green logistics presents an active approach to environmental protection, but in comparison with the standard features of logistics, resp. logistic systems are characterized by several paradoxes that can be observed in the area of externalization mitigation. [2]

In summary, during the process of Globalisation, there are the emergence of the global problems and negative consequences, such as global warming and climate change, the increasing unequal distribution of income and welfare, the abuse and invasion of human rights and others. These elements promote the focus and implement of corporate social responsibilities when multinational corporates employ international business and trade. Moreover, the worldwide competition and consumers' and shareholders' perception make the firms recognize and rethink corporate social responsibility and decision making process concerning environmental, social and ethical issues.

\section{Research Methodology}

The review of literary sources shows the knowledge in connection especially transport logistics, as a factor that can increase the level and quality of sustainable business development. From the point of view of the research approach, the analysis will examine elements of sustainable development of the company with an emphasis on green marketing in relation to green logistics. Particular attention in the analysis and synthesis of knowledge is devoted to the impact of globalization on Corporate Social Responsibility and Supply Chain Management, with an emphasis on green logistics. These elements make an important contribution to the sustainable development of the business, to which the relevant documents of the European Commission bind us. Research methodology will include historical method, desk review, system analysis and field research 


\section{Sustainable Business Development}

A part of the scale economy and competitive advantage as the main advantages, the globalized organizations are deeply involved in achieving sustainability and greening the global economy. [3] In addition to traditional business reliability and business ethics, environmental considerations also play an important role in the company's reputation. The classic marketing mix in the business replaces the green marketing mix. The green concept of product design, sales and sponsorship orientation, public relations, green transport, product and packaging reprocessing, programs to minimize waste generation as well as product labelling to inform consumers about meeting environmental standards and many other examples can be included in " Green "strategy of a modern enterprise. Consumers around the world increasingly prefer organic products, but on the other they expect more from the businesses that offer such products. Green marketing is therefore an indispensable tool in influencing consumption towards responsible environmental behaviour. However, the implementation of sustainable development "that meets the basic needs of all people without compromising the ability of future generations to meet their own life-sustaining. [4]

Typically, Logistics is seen as the actions of which the objective is to minimize costs and maximize profits. The term was used mostly in purely business areas exhibiting companies and in financial reports. But, for many years, the term logistics was used in conjunction with the "green" by creating "Green Logistics" - the term containing costs, yet did not appear on financial reports and on the environment and society. The term "green logistics" is defined as supply chain management practices and strategies that reduce the environmental and energy footprint of freight distribution, which focuses on material handling, waste management, packaging and transport. [5] We adopt three moderating factors-market demand pull, regulation, and technology push-that strengthen the positive effect of proactive environmental strategies on reverse Logistics management [6].

\subsection{Green Marketing}

Green marketing refers to the process of selling products and/or services based on their environmental benefits. Such a product or service may be environmentally friendly in itself or produced in an environmentally friendly way, including:

- Being manufactured in a sustainable fashion;

- Not containing toxic materials or ozone-depleting substances;

- Able to be recycled and/or is produced from recycled materials;

- Being made from renewable materials (such as bamboo, etc.);

- Not making use of excessive packaging;

- Being designed to be repairable and not "throwaway".

Green marketing is typically practiced by companies that are committed to sustainable development and corporate social responsibility. More organizations are making an effort to implement sustainable business practices as they recognize that in doing so they can make their products more attractive to consumers and also reduce expenses, including packaging, transportation, energy/water usage, etc. [7] Businesses are increasingly discovering that demonstrating a high level of social responsibility can increase brand loyalty among socially conscious consumers. The obvious assumption of green marketing is that potential consumers will view a product or service's "greenness" as a benefit and base their buying decision accordingly. [8] The not-so-obvious assumption is that consumers will be willing to pay more for green products than they would for a less-green comparable alternative product.

The Responsibility polled 30,000 consumers from 60 countries to determine statistics on consumer preferences for sustainable purchasing, and found that: 
- $55 \%$ of consumers were willing to pay extra for products and services from companies committed to positive social and environmental impact (up from $45 \%$ in 2011);

- $\quad 52 \%$ made at least one purchase in the past six months from at least one socially responsible company;

- $52 \%$ check product packaging to ensure sustainable impact.

Interestingly, consumers in the Asia-Pacific region, Latin America, and the Middle East/Africa showed a higher preference $(64 \%, 63 \%, 63 \%)$ to pay extra, whereas the preference in North America and Europe was lower (42\% and 40\%). The Nielsen survey also looked at retail purchase statistics, and according to sales data brands that advertised sustainability on packaging had 2\% year-over-year increase in sales from 2011 to 2014, as compared with $1 \%$ for those that did not.

\subsection{Green Logistics}

Green logistics activities include measuring the environmental impact of different distribution strategies, reducing the energy usage in logistics activities, reducing waste and managing its treatment. [9] From the sustainable development point of view, green logistics can be defined as, "producing and distributing goods in a sustainable way, taking account of environmental and social factors". This broad definition of green logistics is in line with the WCED (1987) definition of sustainable development and definitions of corporate responsibility.

The three pillars of Sustainable Development can be applied to green logistics (Figure 1). As mentioned in the definitions of green logistics before, in the past, companies coordinated their logistics activities comprising freight transport, warehousing, packaging, materials handling and data collection and management to meet customer requirements at minimum cost which just refers to the monetary terms. [10] Now, the environment has become a concern. It is treated as a factor of the cost. Some companies have already taken external costs of logistics associated especially with the environmental issues such as climate change, pollution and noise into account. Green logistics is therefore defined as efforts to examine ways of reducing these externalities and achieving a more sustainable balance between environmental, economic and social objectives, (see Figure 1). All efforts in the "green" logistics area are therefore focused on contributing towards, and ensuring, sustainability.

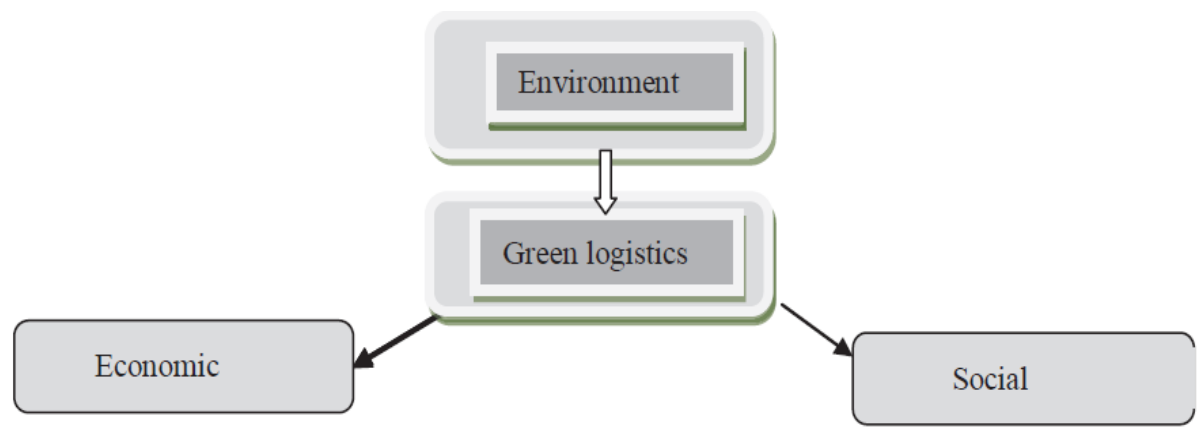

Figure 1. Green logistics as an element of sustainable development.

Over the past 40 years, "Green Logistics" has represented a lot of nature trails, the most distinguishable as follows: 
- reduction in transport costs,

- city logistics,

- corporate environmental strategies towards logistics,

- reverse logistics,

- green supply chain management.

\section{Impacts of Globalization}

Global enterprises are permanently trying to develop new, flexible, applicable and innovative methods to enhance their success and competitiveness. Some of these organizations are enhancing their competitiveness through improvements in their environmental activities performance to comply with environmental law and regulations. The main point of complying with environmental law and regulations is customer's environmental concerns and environmental impact of production and service activities. Besides increasing of awareness of the propensity for environmental pollution within organizations' supply network to cost them in consumer complaints, clean-up and punishment. To response the requirement of environmental law and regulations, minimum standards of environmental performance have become increasingly prevalent in the purchasing agreements of multinational corporations for their local and global suppliers. This requirement has become a new customer expectation from suppliers therefore suppliers have to reduce costs and improve quality and service to complete their responsibility for their customers. Although sustainable supply chain (SC) management has been widely investigated in recent years, the focus has mainly been on the practices adopted by a single company, so missing the big picture at SC level [11].

\subsection{Impacts of Globalization on Corporate Social Responsibility}

In accordance with the theoretical perspective, there are two aspects of the effect of globalisation on corporate social responsibility. First, economic growth not only makes the public and national governments concentrate on welfare augmentation and its benefits for the society, but also makes them recognize that economic development is the consequence of the combination of social, economic and moral implications In ideal environment, economic growth will provide the equal distribution of income and welfare, the respect and protection of human rights and other aspects, which all people will share. However, globalisation to a certain extent further intensifies the phenomenon on inequality. During this process, who to be responsible for the balance between economic growth and inequality is considered as the significant path of coping with the negative consequences of globalisation. We can emphasize that governments, firms, consumers are described as the principal undertaker. For firms, they are significant undertakers responsible for the public and social interests and moral issues. The firms incorporate social, environmental and moral issues into the process of their decision making and take the rational responsible behaviour and activities, which brings more and more profits for their shareholders and interests for their stakeholders in the long term [12].

Second, during the process of globalisation, the firms can maximize the efficiency and the performance of firms' business through the worldwide allocation of resources. Nevertheless, the firms encounter the fierce competition beyond the spectrum of country or area. The competition not only brings more value and interests for their consumers, but also makes firms rethink their concerns of social, ethical and environmental issues and decision making process. There is a fact that more and more consumers concern the perception of firms' environmental and social issues and socially responsible behaviours. Furthermore, 
the shareholders and stakeholders also focus on the implement of the strategies on environment and social communities. They will invest in the responsible and sustainable companies that produce the benefits and profits in the long term. [13, 14] Based on these facts from consumers and shareholders, more and more companies concentrate on the implementation and development of social responsibility.

\subsection{Impacts of Globalization on Supply Chains (Green Logistics)}

The greening of logistics activities and supply chains means ensuring that these activities are environmentally friendly and not wasteful, and particularly focus on reducing carbon emissions across the entire supply chain. The World Economic Forum (2009) argued that a collaborative responsibility for greening the supply chain resides with three groups: logistics and transport service providers, shippers and buyers as recipients of such services, and both government and non-government policy makers.

Logistics and transport service providers should increase adoption of new technologies, fuels and associated processes where there is a positive business case, deploy network reviews of large closed networks to ensure efficient hierarchies and nodal structures, look to integrate optimization efforts across multiple networks, enable further collaboration between multiple shippers and/or between carriers and look to switch to more environmentally friendly modes within their own networks. Logistics and transport service providers should encourage wider industry commitment to improve existing facilities through retrofitting green technologies and work towards industry-wide commitments to boost investment in new building technologies, and develop new offerings in recycling and waste management, working collaboratively with customers. Policy makers should encourage industry to commit to improvements that consider the boundaries of possibilities with current and future technologies, through individual and sector-wide actions $[15,16]$.

Shippers and buyers should determine how much carbon is designed into a product through raw material selection, the carbon intensity of the production process, the length and speed of the supply chain, and the carbon characteristics of the use phase. Shippers and buyers can take decisions that actively drive positive change up and down the supply chain. Shippers and buyers should agree additional standards and targets on packaging weight and elimination, and seek cross-industry agreements on modularization of transit packaging materials. They should also develop sustainable sourcing policies that consider the carbon impact of primary production, manufacturing and rework activities, and integrate carbon emissions impact into the business case for near-shoring projects. Future research opportunities fall into four major themes: the need for theoretically grounded research, the need for a multi-functional approach, the need for a systems approach that adds strategic insight, and the need for integrated measurement application [17-19].

\section{Conclusion}

Environmental protection has become a serious issue. Transforming environmental protection into business objectives is now a necessary step, not just a sign of goodwill. Various solutions are already available in the world enough to make a company willing to change its situation and invest its time and money. One of the biggest polluters is transport, which is part of logistics. The gradual transition to green logistics is a successful foundation where a business can benefit from cost cutting, improving competitiveness, expanding a good image on the market, possible tax breaks, or other state bonuses.

The importance of green Logistics lies not only in the optimization of Logistics as a whole, but also in increasing the legislative requirements of the state to work with returnable packaging, waste and other materials. The growth of its importance also 
contributes to the promotion of a "green" way of thinking, when managers focus not only on economic indicators, but also try to put the company's activities into an ecological context. Globalization and the growing need for environmental and material protection resources requires a significant improvement in the coordination of different forms of activities and emergence of the new Internet market, logistics becomes even more complex.

Therefore, it would be advisable to continue further research on this subject as the issue has a broad context and the requirement to ensure sustainable development and an adequate quality of life for the population is crucial for any society.

\section{References}

1. T.D. Lambert, J. R. Stock, L. Ellram, Logistika, (2000)

2. E. Tomková, N. Husáková, J. Strohmandl, Transport Means 2015, 694-697 (2015)

3. O. Negulescu, Eco-efficience management in the context of globalization and green investments", $2^{\text {nd }}$ International Conference on Globalization, Intercultural Dialogue and National Identity, 525-531 (2014)

4. P. C. Sauer, S. Seuring, Sustainable Supply Cain for Minerals, Journal of Cleaner Production, 151, pp. 235-249 (2017)

5. J. P. Rodrigue, Supply Chain Management, Logistics Changes and the Concept of Friction. Chapter 4. For Hall and M. Hesse (2012)

6. C. L. Hsu, YC Liao, Sustainability strategies and revers logistics management: a contingent link, Proceeding of IEEE International Conference on Management of Inovation and Technology (ICMIT). (2014)

7. T. Klieštik, T., J. Majerová, A. N. Lyakin, Metamorphoses and Semantics of Corporate Failures as a Basal Assumption of a Well-founded Prediction of a Corporate Financial Health, In: 3rd International Conference on Economics and Social Science, Advances in Education Research, ICESS, 86, 150 - 154, IERI (2015)

8. J. Majerova, Analysis of Slovak Consumer's Perception of the Green Marketing Activities, Procedia Economics and Finance Procedia Economics and Finance, 26, 553-560 (2015)

9. A. Sbihi, R. W. Eglese, Combinatorial optimization and Green Logistics. Annals of Operations Research ,175(1), 159-175 (2009)

10. J. Nowakowska-Grunt, Enterprises. Advanced Logistic systems, 2(1), 71-74 (2008)

11. M. Golini, A. Moretto, F. Caniato, M. Caridi, M. Kalchmidt, Developing Sustainability in the Italien meat Supply Chain: Empirical investigation, International Journal of Production Research, 4, 1183-1209 (2017)

12. P. Durana, P. Kral, V. Stehel, G. Lazaroiu, W. Sroka, Quality Culture of Manufacturing Enterprises: A Possible Way to Adaptation to Industry 4.0, Social Sciences, 8(4), 1-25 (2019)

13. D. Buc, T. Kliestik, A. Krizanova, Description and quantification of risks of intelligent transport systems, In Transport means 2013 : proceedings of the 17th international conference, Kaunas University of Technology, Lithuania, 181-184, (2013)

14. A. Siekelova, T. Kliestik, L. Svabova, A. Androniceanu, J. Schonfeld, Receivables management : the importance of financial indicators in assessing the creditworthiness. 2017. Polish journal of management studies, 15(2), 217-228 (2017)

15. D. Malindžák, Teória Logistiky ( 2007) 
16. J. Mentzer, S. Min, L. Michelle Bobbitt, Analysis of workplaces supply in a production company, Int. J. Phys. Distrib. Logist. Manag. 34, 606-627 (2004)

17. D. Mollenkopf, H. Stolze, W. L. Tate, M. Ueltschy, Green, lean, and global Supply chains", International Journal of Physical Distribution \& Logistics Management , 40, (1-2), 14-41. (2010)

18. W. Sroka, M. Lorinczy, The Perception of Ethics in Business: Analysis of Research Results. Procedia Economics and Finance 34, 156-163 (2015)

19. M. Poliak, A. Krizanova, S. Semanova, L. Stefanikova, The impact of procurement method of the transport services to the financial requirement of performance contracting entity. Transport problems 8, 4, 67-76 (2013) 